Check for updates

Cite this: RSC Adv., 2017, 7, 32877

Received 2nd May 2017

Accepted 19th June 2017

DOI: $10.1039 / c 7 r a 04922 f$

rsc.li/rsc-advances

\section{Epoxide functionalization on cholane side chains in the identification of G-protein coupled bile acid receptor (GPBAR1) selective agonists $\uparrow$}

\author{
Simona De Marino, (iD a Adriana Carino, (D) ${ }^{\mathrm{b}}$ Dario Masullo, ${ }^{\mathrm{a}}$ Claudia Finamore, ${ }^{\mathrm{a}}$ \\ Valentina Sepe, iD a Silvia Marchianò, ${ }^{b}$ Francesco Saverio Di Leva, ${ }^{a}$ \\ Vittorio Limongelli, ${ }^{\text {ac }}$ Stefano Fiorucci ${ }^{\mathrm{b}}$ and Angela Zampella (iD *a
}

\begin{abstract}
The G-protein coupled receptor of bile acids GPBAR1 is a bile acid receptor that plays an important role in regulating innate immunity, glucose homeostasis and energy expenditure representing an interesting target for the treatment of metabolic and degenerative diseases. A selective control of its activity over the other bile acid-activated receptors is desirable to reduce unwanted effects due to activation of multiple downstream signals regulated by diverse receptors. Here, we report the design and the synthesis of a small series of bile acid derivatives with their side chains decorated with an epoxide ring. We demonstrate that all the compounds selectively activate GPBAR1 in cell-based assays and regulate the expression of pro-glucagon, a canonical GPBAR1 targeted gene in an intestinal endocrine cell line, while have no effect on FXR, LXR $\alpha$ and LXR . Finally, we elucidate the binding mode of the most potent compound of this family through molecular modeling studies. Our study contributes to increase the arsenal of bile acid derivatives serving as GPBAR1 modulators, widening the chemical space that can be exploited in drug design.
\end{abstract}

\section{Introduction}

GPBAR1 is the first example of the specific bile acid receptor subclass $^{\mathbf{1 , 2}}$ of human G-protein coupled receptors. GPBAR1 is expressed in several tissues, including non-parenchymal liver cells, gallbladder, ileum, colon, heart, spleen, kidney, placenta, lung, uterus, testis, mammary gland, prostate, skeletal muscle, brown adipose tissue, leukocytes, macrophages, endothelial cells and selected areas of the central nervous system. Activation by secondary bile acids, mainly the tauro conjugated form of lithocholic acid (TLCA, taurolithocholic acid in Fig. 1), increases intracellular levels of cAMP and protein kinase A, allowing signaling transduction. Responses to GPBAR1 activation are tissue-specific. In entero-endocrine L cells, GPBAR1 activation stimulates the release of glucagon-like peptide (GLP)-1, a well characterized incretin that improves insulin release, thus regulating glucose homeostasis, ${ }^{3}$ whereas in muscle and brown adipose tissue, GPBAR1 activation increases energy expenditure

${ }^{a}$ Department of Pharmacy, University of Naples "Federico II", Naples, Italy. E-mail: azampell@unina.it; Fax: +39-081676552; Tel: +39-081678525

${ }^{b}$ Department of Surgery and Biomedical Sciences, Nuova Facoltà di Medicina, Perugia, Italy

'Università della Svizzera Italiana (USI), Faculty of Informatics, Institute of Computational Science - Center for Computational Medicine in Cardiology, Lugano, Switzerland

$\dagger$ Electronic supplementary information (ESI) available: Copies of NMR spectra for all products. See DOI: 10.1039/c7ra04922f and oxygen consumption attenuating diet-induced obesity. ${ }^{4}$ Moreover, GPBAR1 reduces liver steatosis, ${ }^{5}$ regulates gallbladder filling and bile homeostasis, ${ }^{6-8}$ intestinal motility, ${ }^{9}$ itch, and analgesia. ${ }^{10}$ Finally, activation of the GPBAR1 signaling pathway has been reported to beneficially impact on multiple inflammatory diseases, such as atherosclerosis, steatohepatitis and colitis. ${ }^{\mathbf{1 1}}$

Consequently, modulation of GPBAR1 by small molecules has shown promise in the treatment of several human diseases ranging from type 2 diabetes, obesity and liver steatosis to inflammation and cancer. ${ }^{\mathbf{1 2}}$

In the last ten years, chemical modification on bile acid and non-bile acid scaffolds from academia and industries have led to the identification of GPBAR1 modulators. In the context of bile acid mimetics, designing selective GPBAR1 agonists is challenging since bile acids are also agonists for several nuclear receptors, mainly farnesoid $\mathrm{X}$ receptor, FXR, the endogenous sensor of bile acid levels, and the two proteins share major structural requisites for ligand binding. Since FXR and GPBAR1 act on different downstream signals, targeting both receptors could be beneficial in a variety of clinical indications, making dual agonists attractive candidates as potential novel therapeutic options with applications across a range of chronic metabolic and liver diseases. ${ }^{13}$ On the other hand, dual FXR/ GPBAR1 ligands might expose patients to multiple unwanted effects due to activation of the diverse downstream signals controlled by the two receptors. ${ }^{14,15}$ 


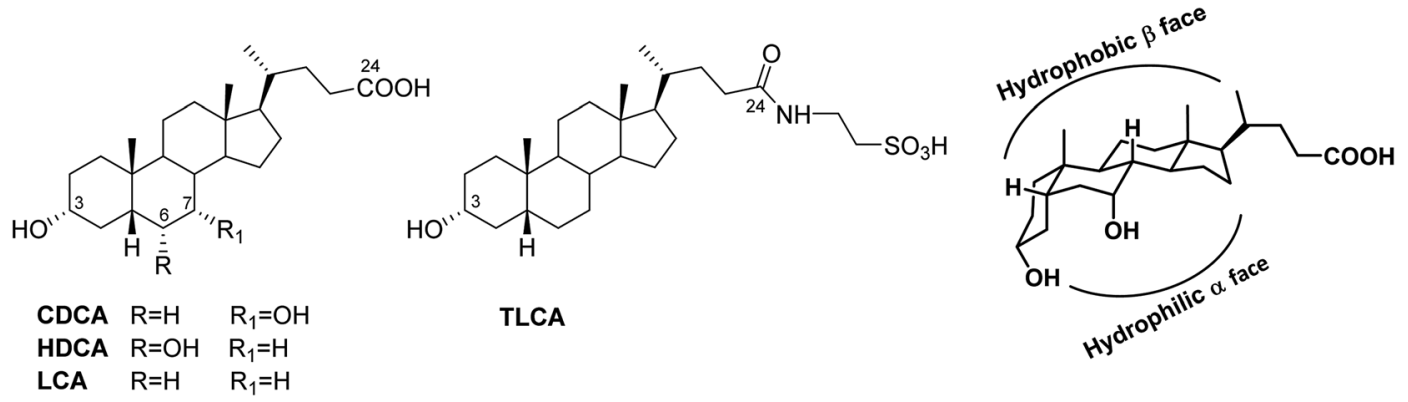

Fig. 1 Endogenous bile acids with their bent shape.

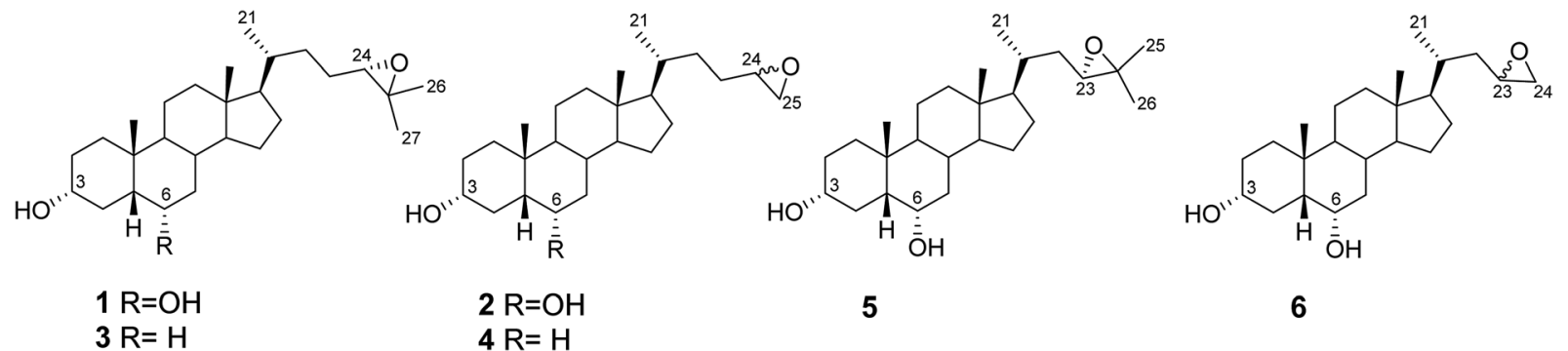

Fig. 2 HDCA derivatives prepared in this study.

Bile acids are truncated side chain steroidal molecules with a carboxyl functional group at $\mathrm{C}-24$ and with the steroidal nucleus adopting a bent shape due to the $\mathrm{A} / \mathrm{B}$ cis ring juncture that forces ring A to lie outside of the plane of the BCD ring system (Fig. 1). In that manner, two well-differentiated surfaces are defined, the hydrophobic convex surface of the tetracyclic core and a hydrophilic surface where the hydroxyl groups lie.

The activity and selectivity of bile acids towards their receptors is related to the index of hydrophilicity that in turn depends on the number, position and configuration of $\mathrm{OH}$ groups. Thus, among human bile acid pool, chenodeoxycholic acid (CDCA) with two hydroxyl group $\alpha$-oriented at C-3 and C-7 is the most potent endogenous FXR agonist, whereas lithocholic acid (LCA) and its tauro-conjugated form (TLCA) are privileged activators of GPBAR1 (Fig. 1). Of interest, the introduction of a hydroxyl group at C-6 as in hyodeoxycholic acid (HDCA), a secondary bile acid generated in human small intestine, ${ }^{\mathbf{1 6}}$ completely abolishes FXR activity whereas retains GPBAR1 modulation showing a weak agonistic profile. ${ }^{17}$

We have recently investigated the chemical space of HDCA, ${ }^{\mathbf{1 8}}$ introducing various apolar side chains and making specific chemical modifications on its steroidal scaffold. This study led to the identification of the first example of LXR $\alpha /$ GPBAR1 dual modulator useful in treatment of metabolic disorders. Here, we have designed and synthesized a new series of HDCA derivatives with the aim of discover novel selective agonists of GBPAR1. Specifically, we have introduced side chains of different length and size containing an epoxide group on the HDCA scaffold, which are endowed of amphipathic properties and thus able to establish both polar and hydrophobic contacts with the receptor counterpart. The rationale of the design is based on our previous computational studies showing that the side chain of GPBAR1 ligands is placed in proximity of an amphipathic region of the receptor. ${ }^{\mathbf{1 3 b , 1 8 , 1 9 , 2 0}}$ The novel ligands described in this study were expected to preserve or even enhance affinity towards GPBAR1. Furthermore, since FXR agonists typically have polar side chains, mainly carboxylic or alcoholic end groups, the epoxide compounds should show a preferred activity towards GPBAR1 over FXR. ${ }^{13 d}$

In addition to the side chain of HDCA, we have also modified the substituent at the C- 6 position of the steroidal scaffold and investigated the ability of the newly synthesized HDCA analogues (1-6, Fig. 2) to activate GPBAR1 in cell-based assays and to regulate the expression of GPBAR1 targeted genes. The selectivity profile of the new compounds towards GPBAR1 over other pharmacologically relevant bile acid receptors such as FXR, LXR $\alpha$ and LXR $\beta$ is also reported along with molecular modeling studies on GPBAR1.

\section{Results and discussion}

\subsection{Chemistry}

Aldehyde 7 was used as intermediate in the preparation of compounds 1 and 2 . As previously described, ${ }^{18}$ a four-steps reaction sequence on HDCA methyl ester, including protection of alcoholic functions at C-3 and C-6 (2,6-lutidine, $t$-butyldimethylsilyl trifluoromethanesulfonate, $\mathrm{CH}_{2} \mathrm{Cl}_{2}$ ), reduction of the side chain methyl ester $\left(\mathrm{LiBH}_{4}, \mathrm{MeOH} / \mathrm{THF}\right)$, and subsequent one pot Swern oxidation furnished aldehyde 7 in $76 \%$ chemical yield (Scheme 1).

Wittig olefination with isopropyl triphenylphosphonium iodide followed by the removal of $3 \alpha, 6 \alpha$-dihydroxy protective 


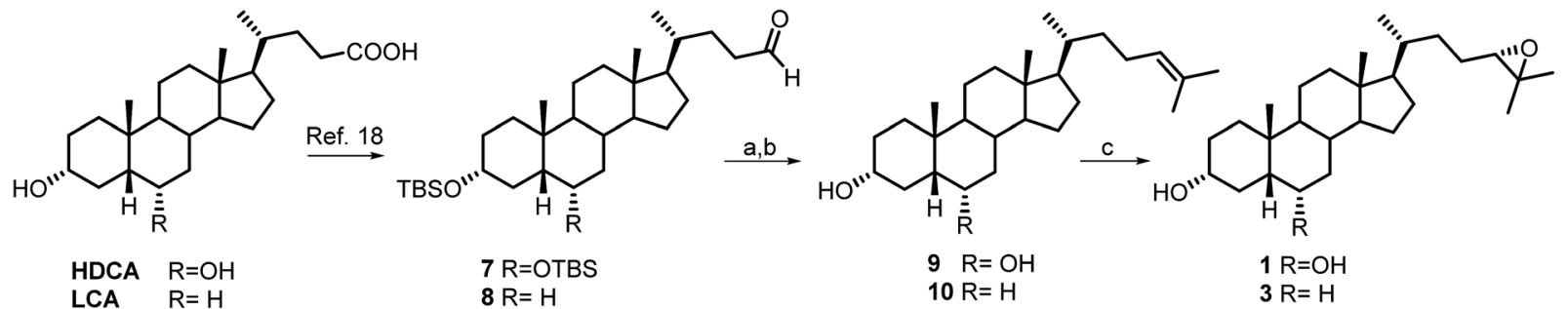

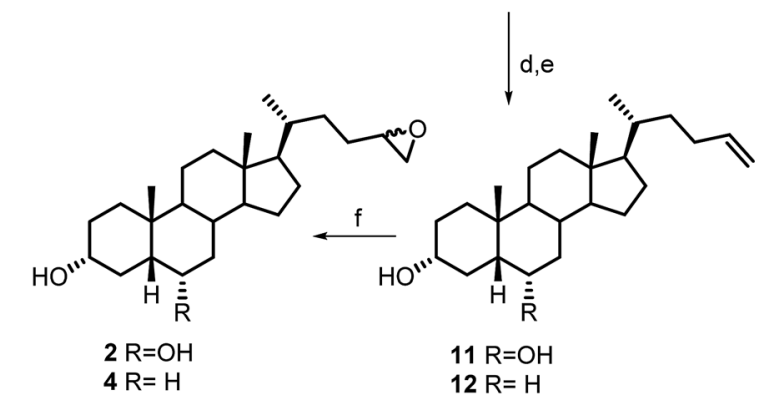

Scheme 1 Synthesis of compounds 1-4. Reagents and conditions: (a) $n$-BuLi, isopropyl triphenylphosponium iodide, THF dry, r.t.; (b) HCl 37\%,

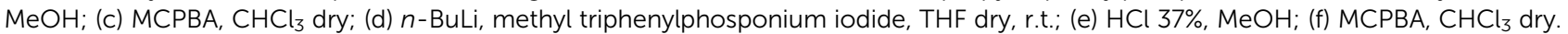

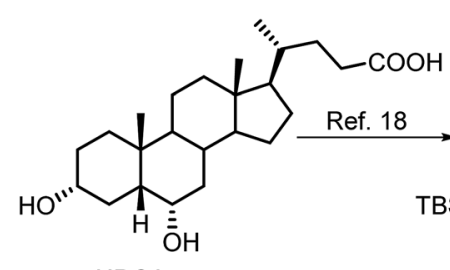

HDCA

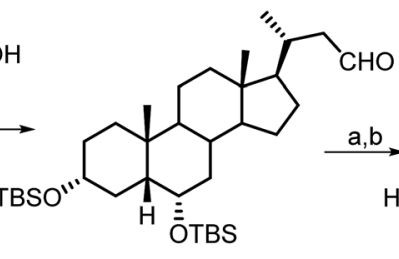

13<smiles>CC(C)=CC[C@H](C)C1CCC2C3C[C@H](O)[C@H]4C[C@@H](Cl)CC[C@]4(C)C3CCC21C</smiles>

14

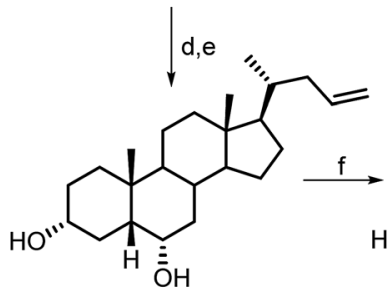

15

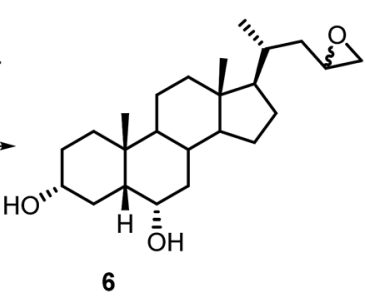

Scheme 2 Synthesis of compounds 5 and 6 . Reagents and conditions: (a) $n$-BuLi, isopropyl triphenylphosponium iodide, THF dry, r.t.; (b) HCl $37 \%, \mathrm{MeOH}$; (c) $\mathrm{MCPBA}, \mathrm{CHCl}_{3}$ dry; (d) $n$-BuLi, methyl triphenylphosponium iodide, THF dry, r.t.; (e) $\mathrm{HCl} 37 \%, \mathrm{MeOH}$; (f) $\mathrm{MCPBA}, \mathrm{CHCl} 3$ dry.

groups gave the unsaturated compound 9 that was also used as starting material in double bound epoxidation with metachloroperbenzoic acid (MCPBA) affording the epoxy derivative 1 in $87 \%$ yield. The $24(S)$ configuration of $\mathbf{1}$ was deduced by the complete agreement of the chemical shifts values of the Me-26 and Me-27 in the side chain with those of 24(S),25epoxycholesterol. $^{21}$

Compound 2 (Scheme 1) was prepared as an inseparable mixture of the two diasteroisomers at C-24 position following the same synthetic protocol described for compound 1, using methyl triphenylphosponium iodide in Wittig olefination and meta-chloroperbenzoic acid (MCPBA) in epoxidation.

To obtain the corresponding 6-deoxy derivatives 3 and 4, LCA methyl ester was subjected to the same four-step sequence depicted for HDCA (Scheme 1). Witting olefination with isopropyl triphenylphosphonium iodide and methyl triphenylphosponium iodide followed by the removal of $3 \alpha$-hydroxy protective group gave the unsaturated compounds $\mathbf{1 0}$ and $\mathbf{1 2}$, respectively, that were used as starting material in double bound epoxidation with meta-chloroperbenzoic acid (MCPBA) affording the epoxy derivatives 3 ( $68 \%$ yield) and 4 , respectively.

Scheme 2 illustrates the synthetic protocols for the preparation of HDCA derivatives $\mathbf{5}$ and $\mathbf{6}$ with nor epoxy side chains. HDCA was transformed in the C-23 protected aldehyde $\mathbf{1 3}$ following our previously published procedure. ${ }^{18,22}$

Wittig olefination and double bond epoxidation in the same operative conditions described for the preparation of derivatives $\mathbf{1}$ and 2, gave the corresponding nor derivatives $\mathbf{5}$ and $\mathbf{6}$.

\subsection{Pharmacological evaluation}

Compounds 1-6 were evaluated in a luciferase reporter assay on HEK-293T cells transiently transfected with human GPBAR1. Cells were stimulated with compounds 1-6 using TLCA, the 


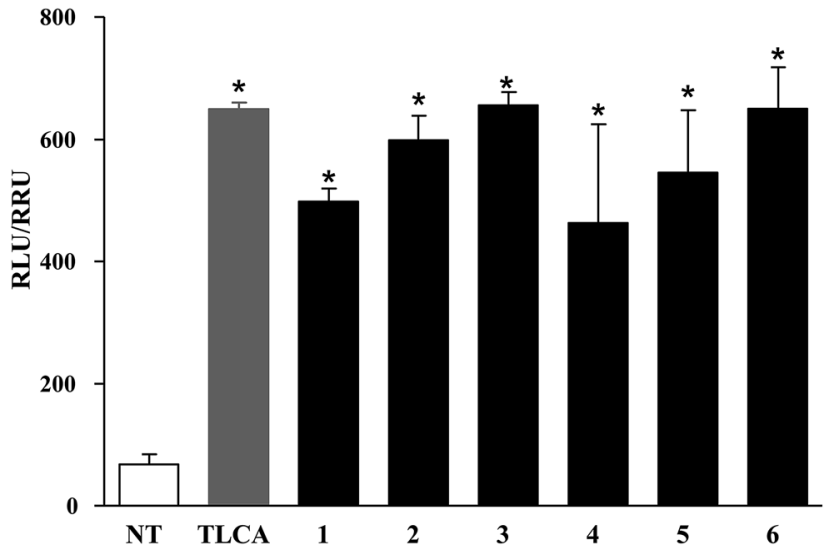

Fig. 3 Agonism on GPBAR1 by transactivation assay. Luciferase reporter assay was performed on HEK-293T cells co-transfected with GPBAR1 and a reporter gene containing a cAMP responsive element in front of the luciferase gene. Cells were stimulated with 1-6 $(10 \mu \mathrm{M})$. TLCA $(10 \mu \mathrm{M})$ was used as a positive control. Luciferase activity served as a measure of the rise in intracellular CAMP following activation of GPBAR1. Value was expressed as RLU/RRU (Relative Luciferase Unit/ Relative Renilla Unit). Results are expressed as mean \pm standard error. $* p<0.05$ versus not treated cells (NT).

most potent endogenous activator of GPBAR1 $(10 \mu \mathrm{M})$, as reference compound. As shown in Fig. 3, all derivatives generated in this study were able to induce cAMP-luciferase reporter gene, with an efficacy at $10 \mu \mathrm{M}$ concentration comparable to that of TLCA.
The relative potency was then investigated by a detailed measurement of the concentration-response curves with 1-6 transactivating GPBAR1 with $\mathrm{EC}_{50}$ values in the range of 1.49$5.80 \mu \mathrm{M}$ (Fig. 4).

Furthermore, compounds 1-6 were evaluated in vitro on common off-targets, such as FXR and LXR $\alpha$ and $\beta$. As showed in Fig. 5, none compound, when tested at $10 \mu \mathrm{M}$ concentration, induced FXR as well as $\operatorname{LXR} \alpha$ and $\operatorname{LXR} \beta$ transactivation on HepG2 cells, thus demonstrating that the introduction of an epoxy functionality on HDCA and LCA scaffold represents a good strategy to obtain potent and selective GPBAR1 agonists.

Considering the reactivity of epoxide compounds, we have analyzed the presence in the GPBAR1 binding site and along the ligand-binding pathway of nucleophilic amino acids that can typically react with epoxide functions (e.g., Cys, Asp). ${ }^{23}$ The analysis has revealed that none of these amino acids is present either in the binding site or along the ligand-binding pathway. However, within our family of GPBAR1 agonists, we have investigated the stability of compounds 1 and 2 as prototypes of a branched and a linear epoxide, respectively, in HEK-293T cell culture medium (D-MEM additioned with 10\% FBS) and in HEK-293T cell culture medium additioned with serine, in order to mimic the chemical environment of the GPBAR1 binding site in which three serine residues are present. HPLC analysis revealed the presence of intact compounds $\mathbf{1}$ and 2 after incubation for $4 \mathrm{~h}$ at $37^{\circ} \mathrm{C}$ in cell medium and in cell medium/serine (Fig. S2 and S3 in the ESI $\dagger$ ), thus demonstrating the stability of
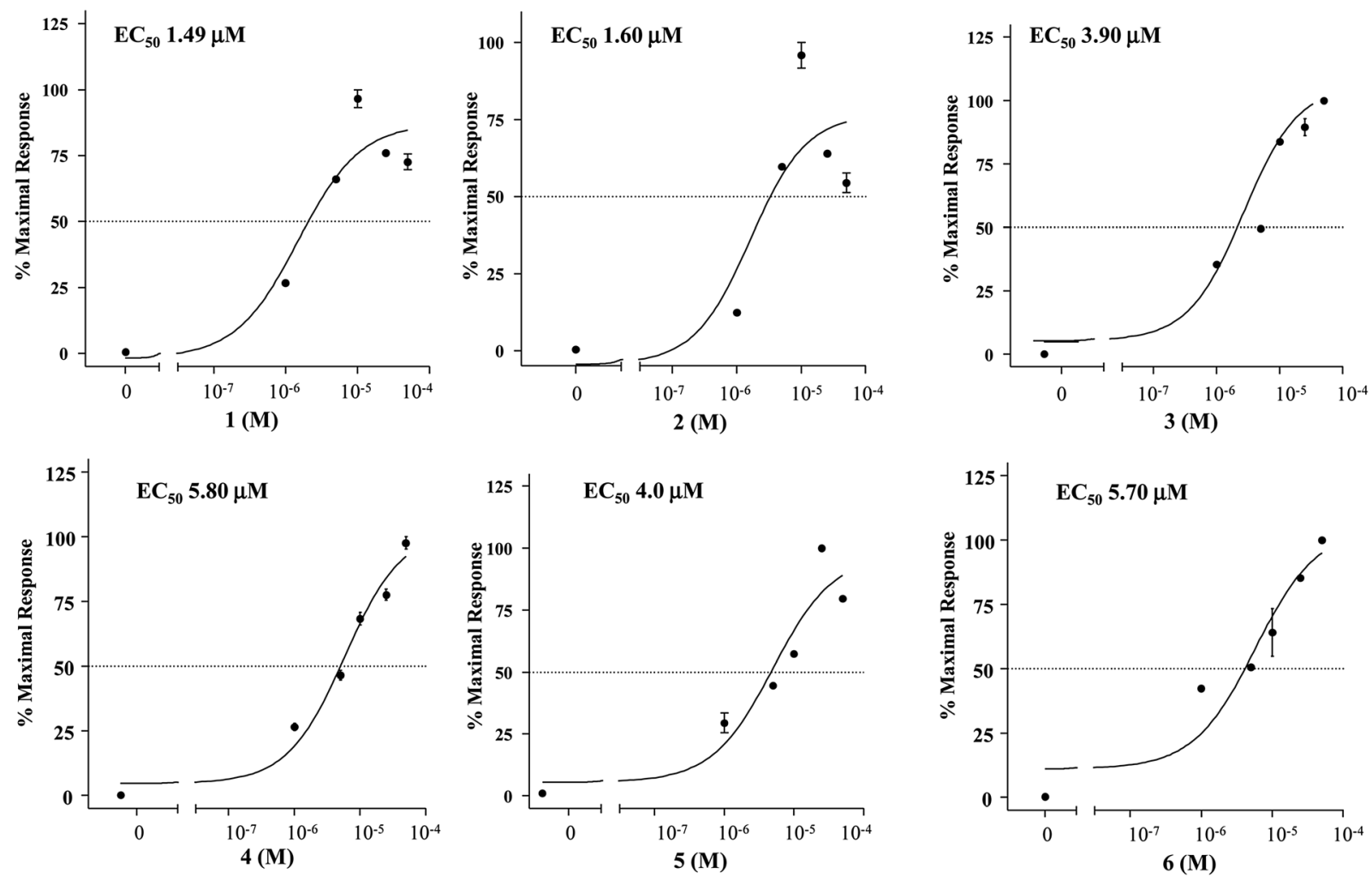

Fig. 4 Concentration-response curve of compounds 1-6 on GPBAR1. GPBAR1 activity was measured in HEK-293T cells co-transfected with GPBAR1 and a reporter gene containing a CAMP responsive element in front of the luciferase gene (CRE). Twenty-four hour post transfection cells were stimulated with increasing concentrations of each agent: range from $1 \mu \mathrm{M}$ to $50 \mu \mathrm{M}$. Results are expressed as mean \pm standard error. 


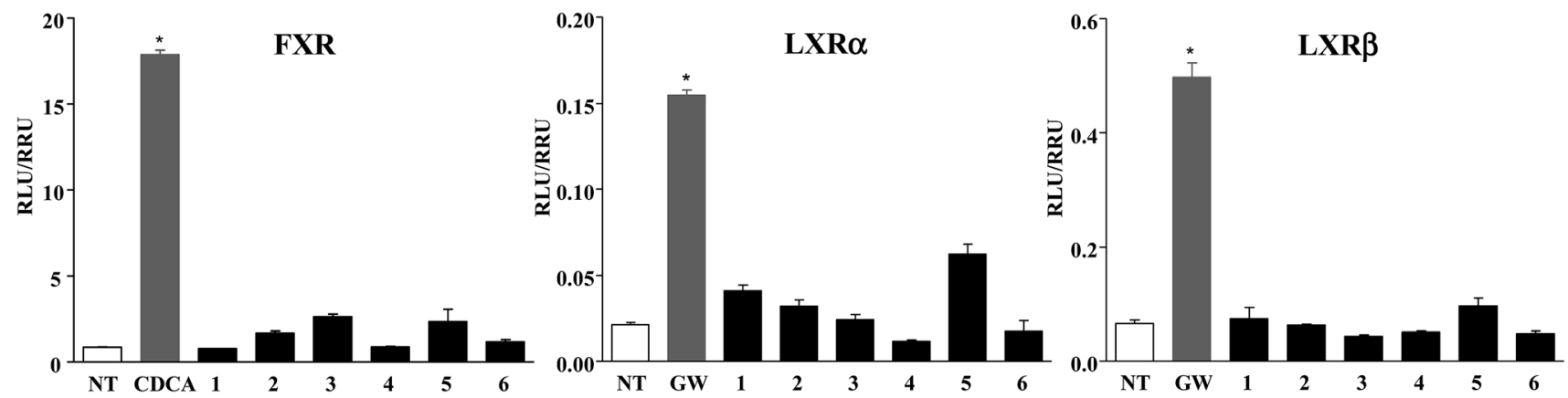

Fig. 5 Specificity of compounds 1-6 on nuclear receptors. (FXR) HepG2 cells were co-transfected with pSG5-FXR, pSG5-RXR, and with the reporter vector phsp27TKLuc and then stimulated $18 \mathrm{~h}$ with CDCA (10 $\mu \mathrm{M})$, a FXR agonist, or with 1-6 (10 $\mu \mathrm{M})$; (LXR $\alpha$ and LXR $\beta)$ HepG2 cells were co-transfected with the Gal4 luciferase reporter vector and with a chimera in which the Gal4 DNA binding domain is fused to the LBD of LXR $\alpha$ or LXR $\beta$, and stimulated $18 \mathrm{~h}$ with GW3965 (10 $\mu \mathrm{M})$, a LXR agonist, or with 1-6 (10 $\mu \mathrm{M})$. Data are the mean \pm SE of three experiments. * $p<0.05$ versus not treated cells (NT).

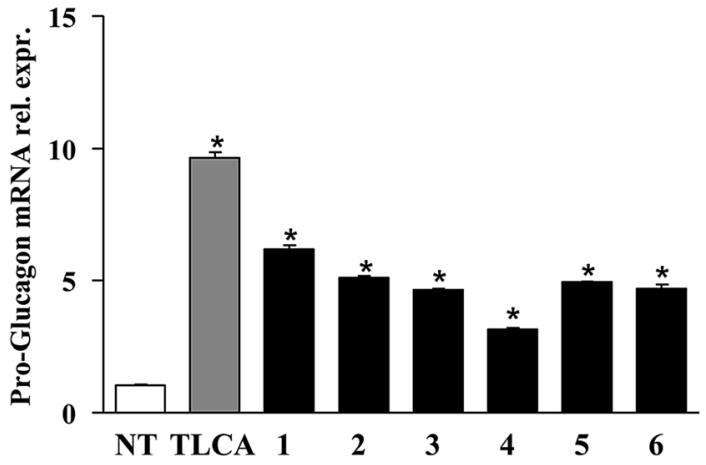

Fig. 6 Effect of compounds 1-6 on pro-glucagon mRNA expression Real-time PCR analysis of mRNA expression of GPBAR1 target gene pro-glucagon in GLUTAg cells stimulated with $10 \mu \mathrm{M}$ TLCA or compounds 1-6. Values are normalized relative to GAPDH mRNA and are expressed relative to those of not treated cells (NT), which are arbitrarily set to 1 . The relative mRNA expression is expressed as $2-$ $\left(\Delta \Delta C_{t}\right) . * p<0.05$ versus NT (non treated cells).

the above compounds in physiological conditions and their non-reactivity within GPBAR1.

Finally, the pharmacological potential of derivatives 1-6 is well demonstrated through RT-PCR data showed in Fig. 6. When administered in vitro on GLUTAg cells, all compounds generated in this study caused a robust increase of the mRNA of proglucagon-1, a GPBAR1 targeted gene. GLUTAg cells are an intestinal enteroendocrine cell line, releasing glucagon-like peptide 1 (GLP-1) by differential processing of proglucagon-1, the gene which is expressed in these cells, in response to GPBAR1 agonists, ${ }^{24}$ therefore are considered a suitable model in evaluating the interactions between GPBAR1 and its ligands. Furthermore, GLP-1 is an appealing pharmacological target in the treatment of diabetes and GLP-1 receptor agonists are currently used in the treatment of type 1 diabetes..$^{25}$

\subsection{Molecular modeling}

In order to investigate the binding mode of the newly synthesized HDCA derivatives to GPBAR1, we performed docking simulation that is a widely used computational technique to generate and rank ligand/protein complexes based on empirical scoring functions. ${ }^{26}$ In the present case, we performed docking calculations on the most potent compound of the series $\mathbf{1}$ in the receptor homology model of GPBAR1 that has been successfully used in our previous drug design studies. ${ }^{13 b, 18,19,20}$ The docking results showed that 1 binds to GPBAR1 similarly to other BA compounds previously investigated by us as agonists of this receptor (Fig. 7). ${ }^{13 b, 18,19,20}$

In particular, the ligand steroidal scaffold establishes a number of hydrophobic interactions with the side chains of Tyr89, Phe96, Leu174 and Trp237 and Tyr240, while the $3 \alpha$ - and $6 \alpha$-hydroxyl groups engage H-bond interactions with Glu169 on the transmembrane helix-5 (TM-5) and with Asn93 on TM3, respectively. The latter interaction is however not fundamental to activate the receptor, in fact, compounds $\mathbf{3}$ and $\mathbf{4}$, which do not present the $6 \alpha-\mathrm{OH}$ group and thus cannot interact with Asn93, display $\mathrm{EC}_{50}$ values comparable to their $6 \alpha$-hydroxylated analogues. On the other side of the binding site, the epoxide side chain of 1 can reach and contact the serine residues on TM1 and TM-7 (Fig. 7). In the same region, the ligand epoxide side chain can even form hydrophobic interactions with the side

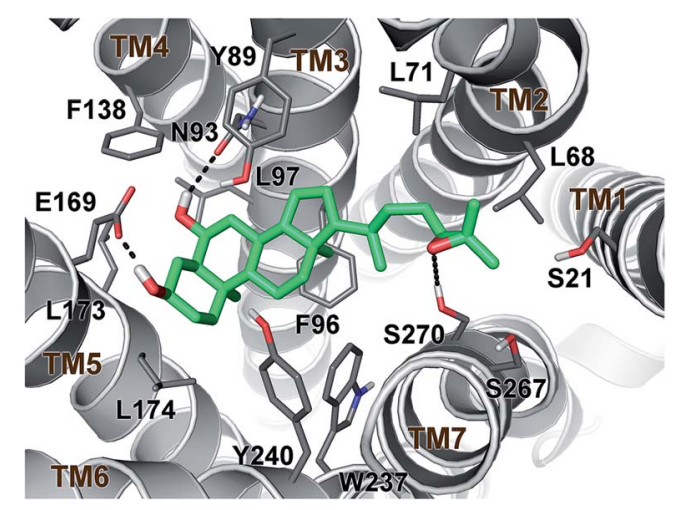

Fig. 7 Binding mode of 1 (green sticks) in hGPBAR1 (gray cartoon). Receptor amino acids important for ligand binding are displayed as sticks. Receptor extracellular loops and all nonpolar hydrogens are omitted for clarity. 
chains of Leu68 and Leu71 and Leu263. The amphipathic nature and the plasticity of this receptor region allow bile acids to accommodate side chains with different steric and electrostatic properties, thus explaining the similar agonist profiles shown by all the epoxide analogues presented in this study.

\section{Experimental}

\subsection{Chemistry}

All chemicals were obtained from Sigma-Aldrich, Inc. Solvents and reagents were used as supplied from commercial sources with the following exceptions. Dichloromethane, tetrahydrofuran and trimethylamine were distilled from calcium hydride immediately prior to use. Methanol was dried from magnesium methoxide as follow. Magnesium turnings (5 g) and iodine (0.5 g) were refluxed in a small $(50-100 \mathrm{~mL})$ quantity of methanol until all of the magnesium has reacted. The mixture was diluted (up to $1 \mathrm{~L}$ ) with reagent grade methanol, refluxed for 2-3 h then distilled under nitrogen. All reactions were carried out under argon atmosphere using flame-dried glassware. Reaction progress was monitored via thin-layer chromatography (TLC) on Alugram silica gel G/UV254 plates. Silica gel MN Kieselgel 60 (70-230 mesh) from Macherey-Nagel Company was used for column chromatography. Tested samples were obtained by HPLC purification on a Waters Model 510 pump equipped with a Waters Rheodine injector and a differential refractometer, model 401 and the purities of compounds were determined to be greater than $95 \%$.

High-resolution ESI-MS spectra were performed with a Micromass Q-TOF mass spectrometer. NMR spectra were obtained on Varian Inova 400, 500 and $700 \mathrm{NMR}$ spectrometer $\left({ }^{1} \mathrm{H}\right.$ at 400,500 and $700 \mathrm{MHz},{ }^{13} \mathrm{C}$ at 100,125 and $175 \mathrm{MHz}$, respectively) equipped with a SUN microsystem ultra 5 hardware and recorded in $\mathrm{CDCl}_{3}\left(\delta_{\mathrm{H}}=7.26\right.$ and $\left.\delta_{\mathrm{C}}=77.0 \mathrm{ppm}\right)$. All of the detected signals were in accordance with the proposed structures. Coupling constants ( $J$ values) are given in hertz $(\mathrm{Hz})$, and chemical shifts $(\delta)$ are reported in ppm and referred to $\mathrm{CHCl}_{3}$ as internal standards. Spin multiplicities are given as $\mathrm{s}$ (singlet), dt (doublet triplet), d (doublet), or m (multiplet).

\subsubsection{Synthetic procedures}

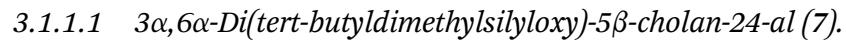
Aldehyde 7 was prepared starting from HDCA as previously described. ${ }^{18}$

3.1.1.2 5 5 -Cholest-24-en-3 $\alpha, 6 \alpha$-diol (9). To a solution of isopropyl triphenylphosphonium iodide $(5.4 \mathrm{~g}, 12.5 \mathrm{mmol})$ in THF ( $2 \mathrm{~mL}$ ), $n$-BuLi (5 mL, $12.5 \mathrm{mmol}$ ) was added dropwise at room temperature until the solution reached a red color. After $30 \mathrm{~min}$, a solution of aldehyde $7(1.5 \mathrm{~g}, 2.5 \mathrm{mmol})$ in THF $(5 \mathrm{~mL})$ was added. After $1 \mathrm{~h}$, the mixture was quenched by addition of saturated aqueous $\mathrm{NaHCO}_{3}(50 \mathrm{~mL})$ and extracted with EtOAc (3 $\times 50 \mathrm{~mL}$ ). The organic phase was dried $\left(\mathrm{Na}_{2} \mathrm{SO}_{4}\right)$ and concentrated. Purification on silica gel (hexane) gave the protected intermediate in $84 \%$ yield. To a solution of this intermediate $(1.3 \mathrm{~g}, 2.1 \mathrm{mmol})$ in $\mathrm{MeOH}, 1 \mathrm{~mL}$ of $\mathrm{HCl} 37 \% \mathrm{v} / \mathrm{v}$ was added. After $1 \mathrm{~h}$, silver carbonate was added, the reaction mixture was centrifuged, and the supernatant was concentrated in vacuo to give compound 9 as a colorless amorphous solid $(850 \mathrm{mg}$, quantitative yield). An analytic sample was purified by HPLC on a Nucleodur 100-5 C18 (5 $\mu \mathrm{m} ; 10 \mathrm{~mm}$ i.d. $\times 250 \mathrm{~mm})$ with $\mathrm{MeOH} / \mathrm{H}_{2} \mathrm{O}(96: 4)$ as eluent (flow rate $3 \mathrm{~mL} \mathrm{~min}^{-1}, t_{\mathrm{R}}=12.0$ min). Selected ${ }^{1} \mathrm{H}$ NMR $\left(400 \mathrm{MHz}, \mathrm{CDCl}_{3}\right): \delta_{\mathrm{H}} 5.10(1 \mathrm{H}, \mathrm{t}, J=$ $6.7 \mathrm{~Hz}, \mathrm{H}-24), 4.08(1 \mathrm{H}, \mathrm{dt}, J=11.9,4.6 \mathrm{~Hz}, \mathrm{H}-6 \beta), 3.64(1 \mathrm{H}, \mathrm{m}$, $\mathrm{H}-3 \beta), 1.68$ (3H, s, Me-26), 1.60 (3H, s, Me-27), 0.92 (3H, d, $J=$ $7.0 \mathrm{~Hz}, \mathrm{Me}-21), 0.91$ (3H, s, Me-19), 0.65 (3H, s, Me-18); ${ }^{13} \mathrm{C}$ NMR $\left(100 \mathrm{MHz}, \mathrm{CDCl}_{3}\right): \delta_{\mathrm{C}} 130.9,125.3,71.6,68.2,56.2(2 \times \mathrm{C}), 48.4$, 42.9, 40.0, 39.9, 36.4, 36.2, 35.6, 35.3, 35.0, 34.9, 30.3, 29.3, 28.4, $25.7,24.7,24.3,23.3,20.9,18.4,17.7,12.1$. HR ESIMS $\mathrm{m} / \mathrm{z}$ $403.3576[\mathrm{M}+\mathrm{H}]^{+}, \mathrm{C}_{27} \mathrm{H}_{46} \mathrm{O}_{2}$ requires 403.3578 .

3.1.1.3 24(S),25-Epoxy-5 $\beta$-cholestan- $3 \alpha, 6 \alpha$-diol (1). To a solution of compound 9 (500 $\mathrm{mg}, 1.24 \mathrm{mmol})$ in $\mathrm{CHCl}_{3}$ dry, metachloroperbenzoic acid was added $(643 \mathrm{mg}, 3.73 \mathrm{mmol})$ at room temperature. The reaction was stirred overnight and then extracted with an aqueous solution of $\mathrm{Na}_{2} \mathrm{SO}_{3}(5 \%)$ and $\mathrm{CH}_{2} \mathrm{Cl}_{2}$ $(3 \times 50 \mathrm{~mL})$ to give compound $1(450 \mathrm{mg}, 87 \%)$. Tested sample was obtained through HPLC (Fig. S1, Panel A in ESI†) on Phenomenex Luna C18 ( $5 \mu \mathrm{m}$; $4.6 \mathrm{~mm}$ i.d. $\times 250 \mathrm{~mm})$ with $\mathrm{MeOH} /$ $\mathrm{H}_{2} \mathrm{O}(85: 15)$ as eluent (flow rate $1 \mathrm{~mL} \mathrm{~min}^{-1}, t_{\mathrm{R}}=15.0 \mathrm{~min}$ ). The $S$ configuration at $\mathrm{C} 24$ was determined in comparison with ${ }^{1} \mathrm{H}-\mathrm{NMR}$ data reported in literature for $24(S), 25$-epoxycholesterol. ${ }^{21}{ }^{1} \mathrm{H}$ NMR (700 $\mathrm{MHz}, \mathrm{CDCl}_{3}$ ) and ${ }^{13} \mathrm{C}$ NMR (175 $\mathrm{MHz}, \mathrm{CDCl}_{3}$ ) in Tables 1 and 2, ESI; $\dagger$ HR ESIMS $m / z$ 419.3525 [M $+\mathrm{H}]^{+}, \mathrm{C}_{27} \mathrm{H}_{47} \mathrm{O}_{3}$ requires 419.3528 .

3.1.1.4 25-Homo-5 $\beta$-chol-24-en- $3 \alpha, 6 \alpha$-diol (11). Compound 11 (370 mg, $0.99 \mathrm{mmol}, 60 \%$ ) was synthesized, starting from compound 7 ( $1 \mathrm{~g}, 1.65 \mathrm{mmol})$ by an analogous procedure to that detailed above for compound $\mathbf{9}$, using a solution of methyl triphenylphosphonium iodide. An analytic sample was purified by HPLC on a Nucleodur 100-5 C18 $(5 \mu \mathrm{m}$; $10 \mathrm{~mm}$ i.d. $\times 250 \mathrm{~mm})$ with $\mathrm{MeOH} / \mathrm{H}_{2} \mathrm{O}(96: 4)$ as eluent (flow rate $3 \mathrm{~mL} \mathrm{~min}^{-1}$ ) giving pure compound $11\left(t_{\mathrm{R}}=11.2 \mathrm{~min}\right)$. Selected ${ }^{1} \mathrm{H}$ NMR $(400 \mathrm{MHz}$, $\left.\mathrm{CDCl}_{3}\right): \delta_{\mathrm{H}} 5.80(1 \mathrm{H}, \mathrm{m}, \mathrm{H}-24), 4.99(1 \mathrm{H}, \mathrm{d}, J=17.1 \mathrm{~Hz}, \mathrm{H}-25)$, $4.91(1 \mathrm{H}, \mathrm{d}, J=9.8 \mathrm{~Hz}, \mathrm{H}-25), 4.05(1 \mathrm{H}, \mathrm{dt}, J=12.0,4.5 \mathrm{~Hz}$,

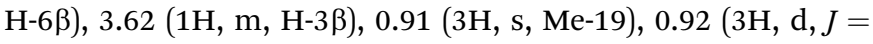
$7.0 \mathrm{~Hz}, \mathrm{Me}-21), 0.64$ (3H, s, Me-18); ${ }^{13} \mathrm{C} \mathrm{NMR} \mathrm{(100} \mathrm{MHz,} \mathrm{CDCl}_{3}$ ): $\delta_{\mathrm{C}} 139.6,113.9,71.6,68.1,56.2,56.1,48.4,42.8,39.9,39.8,36.0$, 35.5, 35.3, 35.2, 35.1, 34.8, 30.5, 30.2, 29.2, 28.2, 24.2, 23.5, 20.7, 18.4, 12.0. HR ESIMS $m / z 375.3263[\mathrm{M}+\mathrm{H}]^{+}, \mathrm{C}_{25} \mathrm{H}_{43} \mathrm{O}_{2}$ requires 375.3266 .

3.1.1.5 24,25-Epoxy-25-homo-5 $\beta$-cholan-3 $\alpha, 6 \alpha$-diol (2). The epoxidation on compound $11(125 \mathrm{mg}, 0.33 \mathrm{mmol})$ has been performed in the same conditions described for compound $\mathbf{1}$ obtaining, crude compound 2. HPLC purification (Fig. S1, Panel $\mathrm{B}$ in the ESI $\dagger$ ) on a Phenomenex Luna C18 (5 $\mu \mathrm{m}$; $4.6 \mathrm{~mm}$ i.d. $\times$ $250 \mathrm{~mm}$ ) with $\mathrm{MeOH} / \mathrm{H}_{2} \mathrm{O}(85: 15)$ as eluent (flow rate $1 \mathrm{~mL}$ $\left.\min ^{-1}\right)$ gave pure $2\left(t_{\mathrm{R}}=11.2 \mathrm{~min}\right)$ as a mixture of two diastereoisomers at C-24 position. ${ }^{1} \mathrm{H}$ NMR $\left(700 \mathrm{MHz}, \mathrm{CDCl}_{3}\right)$ and ${ }^{13} \mathrm{C}$ NMR (175 MHz, $\mathrm{CDCl}_{3}$ ) in Tables 1 and 2, ESI; $\dagger$ HR ESIMS $\mathrm{m} / \mathrm{z}$ $391.3212[\mathrm{M}+\mathrm{H}]^{+}, \mathrm{C}_{25} \mathrm{H}_{43} \mathrm{O}_{3}$ requires 391.3214 .

3.1.1.6 3 $\alpha$-tert-Butyldimethylsilyloxy-5 $\beta$-cholan-24-al Aldehyde 8 (1.8 g, $3.8 \mathrm{mmol}, 72 \%)$, was synthesized starting from LCA ( $2 \mathrm{~g}, 5.3 \mathrm{mmol})$ as previously described. ${ }^{18}$

3.1.1.7 5 $\beta$-Cholest-24-en-3 $\alpha$-ol (10). Compound $10(367 \mathrm{mg}$, $0.95 \mathrm{mmol}, 40 \%$ over two steps) was prepared from 8 (900 mg, $1.9 \mathrm{mmol}$ ) as detailed for compound $\mathbf{9}$. An analytic sample was 
purified by HPLC on a Nucleodur 100-5 C18 (5 $\mu \mathrm{m}$; $4.6 \mathrm{~mm}$ i.d. $\times 250 \mathrm{~mm}$ ) with $\mathrm{MeOH} / \mathrm{H}_{2} \mathrm{O}(99: 1)$ as eluent (flow rate $1 \mathrm{~mL}$ $\left.\min ^{-1}, t_{\mathrm{R}}=12.4 \mathrm{~min}\right)$. Selected ${ }^{1} \mathrm{H}$ NMR (400 MHz, $\left.\mathrm{CDCl}_{3}\right): \delta_{\mathrm{H}}$ $5.08(1 \mathrm{H}, \mathrm{t}, J=6.6 \mathrm{~Hz}, \mathrm{H}-24), 3.62(1 \mathrm{H}, \mathrm{m}, \mathrm{H}-3 \beta), 1.68(3 \mathrm{H}, \mathrm{s}, \mathrm{Me}-$ 26), 1.60 (3H, s, Me-27), 0.92 (3H, ovl, Me-21), 0.92 (3H, s, Me19), 0.64 (3H, s, Me-18); ${ }^{13} \mathrm{C}$ NMR (100 MHz, $\left.\mathrm{CDCl}_{3}\right): \delta_{\mathrm{C}} 130.9$, 125.2, 71.9, 56.5, 56.2, 42.7, 42.1, 40.4, 40.2, 36.5, 36.1, 35.8, 35.6, 35.3, 34.6, 30.6, 28.3, 27.2, 26.4, 25.7, 24.7, 24.2, 23.4, 20.8, 18.6, 17.6, 12.0. HR ESIMS $m / z 387.3620[\mathrm{M}+\mathrm{H}]^{+}, \mathrm{C}_{27} \mathrm{H}_{47} \mathrm{O}$ requires 387.3623 .

3.1.1.8 24(S),25-Epoxy-5 $\beta$-cholestan- $3 \alpha$-ol (3). Compound 3 ( $213 \mathrm{mg}, 68 \%)$ was prepared from $10(300 \mathrm{mg}, 0.78 \mathrm{mmol})$ by the procedure detailed for 1 . Tested sample was obtained by HPLC purification on Nucleodur 100-5 C18 $(5 \mu \mathrm{m}$; $4.6 \mathrm{~mm}$ i.d. $\times 250$ $\mathrm{mm}$ ) with $\mathrm{MeOH} / \mathrm{H}_{2} \mathrm{O}(92: 8)$ as eluent (flow rate $1 \mathrm{~mL} \mathrm{~min}^{-1}, t_{\mathrm{R}}$ $=16.0 \mathrm{~min}) .{ }^{1} \mathrm{H}$ NMR (400 MHz, $\left.\mathrm{CDCl}_{3}\right)$ and ${ }^{13} \mathrm{C} \mathrm{NMR}(100 \mathrm{MHz}$, $\mathrm{CDCl}_{3}$ ) in Tables 1 and 3, ESI; $\dagger$ HR ESIMS $m / z$ 403.3576 $[\mathrm{M}+\mathrm{H}]^{+}$, $\mathrm{C}_{27} \mathrm{H}_{47} \mathrm{O}_{2}$ requires 403.3579 .

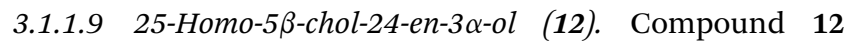
(653 mg, $1.8 \mathrm{mmol}$, quantitative yield over two steps) was prepared from 8 (900 $\mathrm{mg}, 1.9 \mathrm{mmol}$ ) as described for 9, using a solution of methyl triphenylphosphonium iodide. An analytic sample was purified by HPLC on a Nucleodur 100-5 C18 (5 $\mu \mathrm{m}$; $4.6 \mathrm{~mm}$ i.d. $\times 250 \mathrm{~mm}$ ) with $\mathrm{MeOH} / \mathrm{H}_{2} \mathrm{O}(99: 1)$ as eluent (flow rate $\left.1 \mathrm{~mL} \min ^{-1}, t_{\mathrm{R}}=10.2 \mathrm{~min}\right)$. Selected ${ }^{1} \mathrm{H}$ NMR $(400 \mathrm{MHz}$, $\left.\mathrm{CDCl}_{3}\right): \delta_{\mathrm{H}} 5.80(1 \mathrm{H}, \mathrm{m}, \mathrm{H}-24), 4.99(1 \mathrm{H}, \mathrm{d}, J=17.1 \mathrm{~Hz}, \mathrm{H}-25)$, $4.91(1 \mathrm{H}, \mathrm{d}, J=9.8 \mathrm{~Hz}, \mathrm{H}-25), 4.05(1 \mathrm{H}, \mathrm{dt}, J=12.0,4.5 \mathrm{~Hz}$,

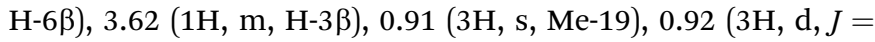
$7.0 \mathrm{~Hz}, \mathrm{Me}-21), 0.64$ (3H, s, Me-18); ${ }^{13} \mathrm{C} \mathrm{NMR}\left(100 \mathrm{MHz}, \mathrm{CDCl}_{3}\right.$ ): $\delta_{\mathrm{C}} 139.6,113.9,71.6,56.5,56.2,42.7,42.2,40.5,40.2,36.5,35.8$, 35.3, 35.2, 34.8, 34.6, 30.5, 30.2, 28.3, 27.2, 26.4, 24.2, 23.5, 20.8, 18.4, 12.0. HR ESIMS $m / z 359.3314[\mathrm{M}+\mathrm{H}]^{+}, \mathrm{C}_{25} \mathrm{H}_{43} \mathrm{O}$ requires 359.3317 .

3.1.1.10 24,25-Epoxy-25-homo-5 $\beta$-cholan-3 $\alpha$-ol (4). Crude compound 4 (521 mg, $1.39 \mathrm{mmol}$ ) was prepared from 12 (500 $\mathrm{mg}, 1.39 \mathrm{mmol}$ ) in the same operative conditions previously described for 2 . Tested sample was obtained as a mixture of two diastereoisomers at C-24 position by HPLC purification on Nucleodur 100-5 C18 (5 $\mu \mathrm{m} ; 4.6 \mathrm{~mm}$ i.d. $\times 250 \mathrm{~mm})$ with $\mathrm{MeOH} / \mathrm{H}_{2} \mathrm{O}(92: 8)$ as eluent (flow rate $1 \mathrm{~mL} \mathrm{~min}^{-1}, t_{\mathrm{R}}=15.1$ min). ${ }^{1} \mathrm{H}$ NMR (400 MHz, $\mathrm{CDCl}_{3}$ ) and ${ }^{13} \mathrm{C}$ NMR $(100 \mathrm{MHz}$, $\mathrm{CDCl}_{3}$ ) in Tables 1 and 3, ESI; $\dagger$ HR ESIMS $m / z 375.3263[\mathrm{M}+\mathrm{H}]^{+}$, $\mathrm{C}_{25} \mathrm{H}_{43} \mathrm{O}_{2}$ requires 375.3265 .

3.1.1.11 $3 \alpha, 6 \alpha$-Di(tert-butyldimethylsilyloxy)-24-nor-5 $\beta$-cholan23-al (13). Aldehyde 13 was prepared from HDCA as previously described..$^{18}$

3.1.1.12 25-nor-5 $\beta$-Cholest-23-en-3 $\alpha, 6 \alpha$-diol (14). Compound 14 (264 mg, $0.7 \mathrm{mmol}$, 80\% over two steps) was prepared from 13 (500 $\mathrm{mg}, 0.85 \mathrm{mmol}$ ) by the same procedure described for 9 . An analytic sample was purified by HPLC on a Nucleodur 100-5 $\mathrm{C} 18(5 \mu \mathrm{m} ; 10 \mathrm{~mm}$ i.d. $\times 250 \mathrm{~mm})$ with $\mathrm{MeOH} / \mathrm{H}_{2} \mathrm{O}(96: 4)$ as eluent (flow rate $3 \mathrm{~mL} \min ^{-1}, t_{\mathrm{R}}=16.0 \mathrm{~min}$ ) giving pure compound 14. Selected ${ }^{1} \mathrm{H}$ NMR (400 MHz, $\left.\mathrm{CD}_{3} \mathrm{OD}\right): \delta_{\mathrm{H}} 5.12$ $(1 \mathrm{H}$, br t $J=6.8 \mathrm{~Hz}, \mathrm{H}-23), 4.01(1 \mathrm{H}, \mathrm{dt}, J=11.9,4.6 \mathrm{~Hz}, \mathrm{H}-6 \beta)$, 3.50 (1H, m, H-3ß), 1.70 (3H, s, Me-26), 1.59 (3H, s, Me-25), 0.93 (3H, s, Me-19), 0.90 (3H, d, $J=6.7 \mathrm{~Hz}, \mathrm{Me}-21), 0.69$ (3H, s, Me18). ${ }^{13} \mathrm{C} \mathrm{NMR}\left(100 \mathrm{MHz}, \mathrm{CD}_{3} \mathrm{OD}\right): \delta_{\mathrm{C}} 132.8,124.2,72.4,68.6,57.6$
$(2 \times \mathrm{C}), 49.9,44.1,41.3(2 \times \mathrm{C}), 38.2,37.0,36.8,36.2,35.6,35.5$, 31.1 , 29.9, 29.5, 26.1, 25.5, 24.1, 21.9, 19.2, 18.0, 12.4. HR ESIMS $m / z 389.3420[\mathrm{M}+\mathrm{H}]^{+}, \mathrm{C}_{26} \mathrm{H}_{45} \mathrm{O}_{2}$ requires 389.3424 .

3.1.1.13 23(S),24-Epoxy-25-nor-5 $\beta$-cholestan-3 $\alpha, 6 \alpha$-diol (5). Epoxidation on compound $14(100 \mathrm{mg}, 0.3 \mathrm{mmol})$ was performed in the same operative conditions described for $\mathbf{1}$, furnishing compound 5 (105 $\mathrm{mg}, 0.26 \mathrm{mmol}, 87 \%$ ). Tested sample was obtained by HPLC on a Nucleodur 100-5 C18 (5 $\mu \mathrm{m}$; $10 \mathrm{~mm}$ i.d. $\times 250 \mathrm{~mm}$ ) with $\mathrm{MeOH} / \mathrm{H}_{2} \mathrm{O}(90: 10)$ as eluent (flow

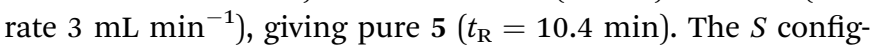
uration was determined in comparison with ${ }^{1} \mathrm{H}$ NMR data reported in literature for compound 24(S),25-epoxycholesterol. ${ }^{21}$ ${ }^{1} \mathrm{H} \mathrm{NMR} \mathrm{(400} \mathrm{MHz,} \mathrm{CDCl}_{3}$ ) and ${ }^{13} \mathrm{C} \mathrm{NMR} \mathrm{(100} \mathrm{MHz,} \mathrm{CDCl}_{3}$ ) in Tables 1 and 2, ESI; $\dagger$ HR ESIMS $m / z 405.3369[\mathrm{M}+\mathrm{H}]^{+}, \mathrm{C}_{26} \mathrm{H}_{45} \mathrm{O}_{3}$ requires 405.3371 .

3.1.1.14 5 3 -Chol-24-en-3 $\alpha, 6 \alpha$-diol (15). Wittig olefination on aldehyde 13 (500 mg, $0.85 \mathrm{mmol}$ ), as described for compound 14, using a solution of methyl triphenylphosphonium iodide, gave compound 15 (290 mg, $0.8 \mathrm{mmol}$, 95\% over two steps). An analytic sample was purified by HPLC on Nucleodur 100-5 C18 $(5 \mu \mathrm{m} ; 10 \mathrm{~mm}$ i.d. $\times 250 \mathrm{~mm})$ with $\mathrm{MeOH} / \mathrm{H}_{2} \mathrm{O}(96: 4)$ as eluent (flow rate $\left.3 \mathrm{~mL} \mathrm{~min}^{-1}\right)$, giving pure compound $15\left(t_{\mathrm{R}}=11.0\right.$ min). Selected ${ }^{1} \mathrm{H}$ NMR (400 MHz, $\left.\mathrm{CDCl}_{3}\right): \delta_{\mathrm{H}} 5.77(1 \mathrm{H}, \mathrm{m}, \mathrm{H}-$ 23), 5.01 (1H, ovl, H-24), 4.99 (1H, ovl, H-24), 4.06 (1H, dt, $J=$

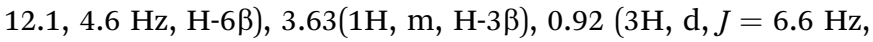
Me-21), 0.91 (3H, s, Me-19), 0.66 (3H, s, Me-18). ${ }^{13} \mathrm{C}$ NMR (100 $\left.\mathrm{MHz}, \mathrm{CDCl}_{3}\right): \delta_{\mathrm{C}} 137.3,115.7,71.6,68.1,56.1,55.8,48.4,42.8$, 40.5 , 39.9, 39.8, 35.9, 35.8, 35.5, 35.1, 34.8, 30.3, 29.2, 28.2, 24.2, 23.5, 20.7, 18.6, 12.0. HR ESIMS $m / z 361.3101[\mathrm{M}+\mathrm{H}]^{+}$, $\mathrm{C}_{24} \mathrm{H}_{41} \mathrm{O}_{2}$ requires 361.3103 .

3.1.1.15 23,24-Epoxy-5 $\beta$-cholan-3 $\alpha, 6 \alpha$-diol (6). Epoxidation on 15 (100 mg, $0.3 \mathrm{mmol}$ ) in the same operative conditions described for 2 furnished crude 6 (108 mg, $0.3 \mathrm{mmol})$. Tested sample was obtained as a mixture of two diastereoisomers at C23 position by HPLC purification on Nucleodur 100-5 C18 (5 $\mu \mathrm{m} ; 4.6 \mathrm{~mm}$ i.d. $\times 250 \mathrm{~mm})$ with $\mathrm{MeOH} / \mathrm{H}_{2} \mathrm{O}(80: 20)$ as eluent (flow rate $\left.1 \mathrm{~mL} \min ^{-1}, t_{\mathrm{R}}=37.5 \mathrm{~min}\right) .{ }^{1} \mathrm{H} \mathrm{NMR}(500 \mathrm{MHz}$, $\mathrm{CD}_{3} \mathrm{OD}$ and $400 \mathrm{MHz}, \mathrm{CDCl}_{3}$ ) and ${ }^{13} \mathrm{C} \mathrm{NMR}\left(100 \mathrm{MHz}, \mathrm{CDCl}_{3}\right)$ in Tables 1 and 2, ESI; $\uparrow$ HR ESIMS $m / z 377.3056[\mathrm{M}+\mathrm{H}]^{+}, \mathrm{C}_{24} \mathrm{H}_{41} \mathrm{O}_{3}$ requires 377.3058 .

\subsection{Biological assay}

3.2.1 Cell culture. HepG2, an immortalized epatocarcinoma cell line, was cultured and maintained at $37{ }^{\circ} \mathrm{C}$ and $5 \%$ $\mathrm{CO}_{2}$ in E-MEM additioned with $10 \% \mathrm{FBS}, 1 \%$ glutamine and $1 \%$ penicillin/streptomycin. HEK-293T and GLUTAg cells were cultured and maintained at $37{ }^{\circ} \mathrm{C}$ and $5 \% \mathrm{CO}_{2}$ in D-MEM additioned with $10 \%$ FBS, $1 \%$ glutamine and $1 \%$ penicillin/ streptomycin.

3.2.2 Luciferase reporter gene assay. To evaluate GPBAR1 mediated transactivation, HEK-293T cells were transfected with $200 \mathrm{ng}$ of human pGL4.29 (Promega), a reporter vector containing a cAMP response element (CRE) that drives the transcription of the luciferase reporter gene luc2P, with $100 \mathrm{ng}$ of pCMVSPORT6-human GPBAR1, and with $100 \mathrm{ng}$ of pGL4.70 (Promega), a vector encoding the human Renilla gene. To 
investigate the specificity of compounds on FXR, HepG2 cells were transfected with $100 \mathrm{ng}$ of human pSG5-FXR, $100 \mathrm{ng}$ of human pSG5-RXR, $200 \mathrm{ng}$ of the reporter vector $\mathrm{p}$ (hsp27)-TKLUC containing the FXR response element IR1 cloned from the promoter of heat shock protein 27 (hsp27) and with $100 \mathrm{ng}$ of pGL4.70. To evaluate the specificity of compounds on LXR $\alpha$ and LXR $\beta$, HepG2 cells were transfected with $200 \mathrm{ng}$ of the reporter vector $\mathrm{p}(\mathrm{UAS}) 5 \mathrm{XTKLuc}, 100 \mathrm{ng}$ of a vector containing the ligand binding domain of LXR $\alpha$ or LXR $\beta$ cloned upstream of the GAL4-DNA binding domain (i.e. pSG5-LXR $\alpha$ LBD-GAL4DBD or pSG5-LXRßLBD-GAL4DBD) and $100 \mathrm{ng}$ of pGL4.70. At $24 \mathrm{~h}$ post-transfection, cells were stimulated $18 \mathrm{~h}$ with $10 \mu \mathrm{M}$ TLCA, CDCA, GW3965 and compounds 1-6. Luciferase activities were assayed and normalized with Renilla activities. To calculate the $\mathrm{EC}_{50}$ of 1-6 versus GPBAR1, a dose-response curve was performed in HEK-293T transfected as described above and stimulated $18 \mathrm{~h}$ with $1,5,10,25$ and $50 \mu \mathrm{M}$ of compounds. After treatments, $10 \mu \mathrm{L}$ of cellular lysates were read using Dual Luciferase Reporter Assay System (Promega Italia srl, Milan, Italy) according manufacturer specifications using the Glomax20/20 luminometer (Promega Italia srl, Milan, Italy). Luciferase activities were assayed and normalized with Renilla activities.

3.2.3 Real-time PCR. Total RNA was isolated from GLUTAg cells using the TRIzol reagent according to the manufacturer's specifications (Invitrogen). One microgram of purified RNA was treated with DNase-I and reverse transcribed with Superscript II (Invitrogen). For Real Time PCR, 25 ng template was dissolved in $20 \mu \mathrm{L}$ containing $200 \mathrm{nmol} \mathrm{L}^{-1}$ of each primer and $12.5 \mu \mathrm{L}$ of $2 \times$ SYBR FAST Universal ready mix (Invitrogen). All reactions were performed in triplicate, and the thermal cycling conditions were as follows: $2 \mathrm{~min}$ at $95^{\circ} \mathrm{C}$, followed by 40 cycles of $95^{\circ} \mathrm{C}$ for $20 \mathrm{~s}$ and $60{ }^{\circ} \mathrm{C}$ for $30 \mathrm{~s}$ in StepOnePlus (Applied Biosystems). The relative mRNA expression was calculated and expressed as $2-$ $\left(\Delta \Delta C_{\mathrm{t}}\right)$. Forward and reverse primer sequences were the following: mouse GAPDH, ctgagtatgtcgtggagtctac and gttggtggtgcaggatgcattg; mouse pro-glucagon, tgaagacaaacgecactcac and caatgttgttceggttcctc.

\subsection{Stability of compound 1 and compound 2 in cell medium and toward serine amino acid}

One microliter of individual $60 \mu \mathrm{M}$ solutions in DMSO of the compound 1 and compound 2 was diluted either in $499 \mu \mathrm{L}$ of cell medium (D-MEM additioned with $10 \%$ FBS) or in $499 \mu \mathrm{L}$ of cell medium additioned with 5 equivalent of serine in a $1.5 \mathrm{~mL}$ Eppendorf. The Eppendorf were gently shaken $4 \mathrm{~h}$ at $37^{\circ} \mathrm{C}$ and injected on an HPLC apparatus equipped with a differential refractometer, model 401. Analysis was performed on Phenomenex Luna C18 (5 $\mu \mathrm{m}$; $4.6 \mathrm{~mm}$ i.d. $\times 250 \mathrm{~mm}$ ) column with $\mathrm{MeOH} / \mathrm{H}_{2} \mathrm{O}(85: 15)$ as eluent (flow rate $1 \mathrm{~mL} \mathrm{~min}^{-1}$ ). One microliter of individual DMSO solutions of compound 1 and compound 2 was also diluted in $499 \mu \mathrm{L}$ of $\mathrm{MeOH} / \mathrm{H}_{2} \mathrm{O}(85: 15)$. For each sample, the stability was determined comparing HPLC peak area of the sample in the standard solution with HPLC peak area in cell medium and in cell medium additioned with serine.

\subsection{Molecular docking}

The Glide (version 7.1) software package ${ }^{27}$ was used to perform molecular docking calculations in the three-dimensional model of hGPBAR1. ${ }^{13 b}$ Ligand and receptor structures were prepared as described in a previous paper. ${ }^{19}$ A box centered on the GPBAR1 binding cavity was created; the Cartesian coordinates of the box, $X, Y$, and $Z$ length were all set to $24.74,26.74,22.74 \AA$, respectively. The standard precision (SP) mode of the GlideScore function was used to score the predicted binding poses. All the residue labels were taken from the wild-type amino acidic sequence of human GPBAR1. All figures were rendered using PyMOL (http://www.pymol.org).

\section{Conclusions}

With the aim at developing selective agonists of GPBAR1, we have described a novel family of HDCA-derivatives. All of these compounds activate the receptor in cell-based assay displaying $\mathrm{EC}_{50}$ values in the low micromolar range and increase the release of GLP-1, a well validated GPBAR1 target, from GLUTAg cells, a murine cell line of intestinal endocrine $\mathrm{L}$ cells. Remarkably, the novel derivatives result inactive on common off-targets of GPBAR1 ligands, such as LXRs and FXR and this finding leads to the conclusion that the introduction of an epoxide group on the bile acid side chain can shift ligand selectivity towards GPBAR1 over FXR and other nuclear receptors. These aspects have been investigated through molecular docking studies disclosing the binding mode to GPBAR1 of the newly synthesized BA derivatives and providing new valuable hints for the selective modulation of the membrane bile acid receptor.

The present results contribute to increase the arsenal of bile acids derivatives serving as GPBAR1 modulators, widening the chemical space that can be exploited in drug design and paving the way for testing the novel derivatives in rodent models of common metabolic disorders including obesity and diabetes.

\section{Conflict of interest}

The authors declare no conflict of interest.

\section{Acknowledgements}

This work was supported by grants from MIUR-ITALY PRIN2015 "Top-down and Bottom-up approach in the development of new bioactive chemical entities inspired on natural products scaffolds" (Project No. 2015MSCKCE_003) and the Swiss National Science Foundation (Project No. 200021_163281). The authors thank European Cooperation in Science and Technology (COST Action CA15135; multi-target paradigm for innovative ligand identification in the drug discovery process) for the support.

\section{Notes and references}

1 Y. Kawamata, R. Fujii, M. Hosoya, M. Harada, H. Yoshida, M. Miwa, S. Fukusumi, Y. Habata, T. Itoh, Y. Shintani, 
S. Hinuma, Y. Fujisawa and M. Fujino, J. Biol. Chem., 2003, 278, 9435-9440.

2 T. Maruyama, Y. Miyamoto, T. Nakamura, Y. Tamai, H. Okada, E. Sugiyama, T. Nakamura, H. Itadani and K. Tanaka, Biochem. Biophys. Res. Commun., 2002, 298, 714719.

3 D. P. Kumar, S. Rajagopal, S. Mahavadi, F. Mirshahi, J. R. Grider, K. S. Murthy and A. J. Sanyal, Biochem. Biophys. Res. Commun., 2012, 427, 600-605.

4 M. Watanabe, S. M. Houten, C. Mataki, M. A. Christoffolete, B. W. Kim, H. Sato, N. Messaddeq, J. W. Harney, O. Ezaki, T. Kodama, K. Schoonjans, A. C. Bianco and J. Auwerx, Nature, 2006, 439, 484-489.

5 G. Vassileva, W. Hu, L. Hoos, G. Tetzloff, S. Yang, L. Liu, L. Kang, H. R. Davis, J. A. Hedrick, H. Lan, T. Kowalski and E. L. Gustafson, J. Endocrinol., 2010, 205, 225-232.

6 V. Keitel, K. Cupisti, C. Ullmer, W. T. Knoefel, R. Kubitz and D. Häussinger, Hepatology, 2009, 50, 861-870.

7 T. Li, S. R. Holmstrom, S. Kir, M. Umetani, D. R. Schmidt, S. A. Kliewer and D. J. Mangelsdorf, Mol. Endocrinol., 2011, 25, 1066-1071.

8 N. Pean, I. Doignon, I. Garcin, A. Besnard, B. Julien, B. Liu, S. Branchereau, A. Spraul, C. Guettier, L. Humbert, K. Schoonjans, D. Rainteau and T. Tordjmann, Hepatology, 2013, 58, 1451-1460.

9 F. Alemi, D. P. Poole, J. Chiu, K. Schoonjans, F. Cattaruzza, J. R. Grider, N. W. Bunnett and C. U. Corvera, Gastroenterology, 2013, 144, 145-154.

10 F. Alemi, E. Kwon, D. P. Poole, T. Lieu, V. Lyo, F. Cattaruzza, F. Cevikbas, M. Steinhoff, R. Nassini, S. Materazzi, R. Guerrero-Alba, E. Valdez-Morales, G. S. Cottrell, K. Schoonjans, P. Geppetti, S. J. Vanner, N. W. Bunnett and C. U. Corvera, J. Clin. Invest., 2013, 123, 1513-1530.

11 V. Z. Rocha and P. Libby, Nat. Rev. Cardiol., 2009, 6, 399-409.

12 (a) S. Fiorucci, A. Mencarelli, G. Palladino and S. Cipriani, Trends Pharmacol. Sci., 2009, 30, 570-580; (b) A. Tiwari and P. Maiti, Drug Discovery Today, 2009, 14, 523-530; (c) S. Fiorucci, S. Cipriani, F. Baldelli and A. Mencarelli, Prog. Lipid Res., 2010, 49, 171-185.

13 (a) S. Fiorucci, A. Mencarelli, E. Distrutti, G. Palladino and S. Cipriani, Curr. Med. Chem., 2010, 17, 139-159; (b) C. D'Amore, F. S. Di Leva, V. Sepe, B. Renga, C. Del Gaudio, M. V. D'Auria, A. Zampella, S. Fiorucci and V. Limongelli, J. Med. Chem., 2014, 57, 937-954; (c) C. Festa, B. Renga, C. D'Amore, V. Sepe, C. Finamore, S. De Marino, A. Carino, S. Cipriani, M. C. Monti, A. Zampella and S. Fiorucci, J. Med. Chem., 2014, 57, 8477-8495; (d) V. Sepe, E. Distrutti, V. Limongelli, S. Fiorucci and A. Zampella, Future Med. Chem., 2015, 7, 1109-1135; (e) S. Fiorucci and E. Distrutti, Trends Mol. Med., 2015, 21, 702-714; (f) C. Finamore, C. Festa, B. Renga, V. Sepe, A. Carino, D. Masullo, M. Biagioli, S. Marchianò, A. Capolupo, M. C. Monti, S. Fiorucci and A. Zampella, Sci.
Rep., 2016, 6, 29320; (g) A. Carino, S. Cipriani, S. Marchianò, M. Biagioli, C. Santorelli, A. Donini, A. Zampella, M. C. Monti and S. Fiorucci, Sci. Rep., 2017, 7, 42801.

14 F. G. Schaap, M. Trauner and P. L. Jansen, Nat. Rev. Gastroenterol. Hepatol., 2014, 11, 55-67.

15 S. Cipriani, B. Renga, C. D'Amore, M. Simonetti, A. A. De Tursi, A. Carino, M. C. Monti, V. Sepe, A. Zampella and S. Fiorucci, PLoS One, 2015, 10, e0129866.

16 H. J. Eyssen, G. De Pauw and J. Van Eldere, Appl. Environ. Microbiol., 1999, 65, 3158-3163.

17 H. Sato, A. Macchiarulo, C. Thomas, A. Gioiello, M. Une, A. F. Hofmann, R. Saladin, K. Schoonjans, R. Pellicciari and J. Auwerx, J. Med. Chem., 2008, 51, 1831-1841.

18 S. De Marino, A. Carino, D. Masullo, C. Finamore, S. Marchianò, S. Cipriani, F. Saverio Di Leva, E. Novellino, B. Catalanotti, V. Limongelli, S. Fiorucci and A. Zampella, Sci. Rep., 2017, 7, 43290.

19 V. Sepe, B. Renga, C. Festa, C. D'Amore, D. Masullo, S. Cipriani, F. S. Di Leva, M. C. Monti, E. Novellino, V. Limongelli, A. Zampella and S. Fiorucci, J. Med. Chem., 2014, 57, 7687-7701.

20 F. S. Di Leva, C. Festa, B. Renga, V. Sepe, E. Novellino, S. Fiorucci, A. Zampella and V. Limongelli, Sci. Rep., 2015, 5, 16605.

21 N. C. O. Tomkinson, T. M. Willson, J. S. Russel and T. A. Spencer, J. Org. Chem., 1998, 63, 9919-9923.

22 V. Sepe, R. Ummarino, M. V. D'Auria, B. Renga, S. Fiorucci and A. Zampella, Eur. J. Org. Chem., 2012, 5187-5194.

23 (a) M. A. Argiriadi, C. Morisseau, B. D. Hammock and D. W. Christianson, Proc. Natl. Acad. Sci. U. S. A., 1999, 96, 10637-10642; (b) G. A. Gomez, C. Morisseau, B. D. Hammock and D. W. Christianson, Biochemistry, 2004, 43, 4716-4723.

24 H. E. Parker, K. Wallis, C. W. le Roux, K. Y. Wong, F. Reimann and F. M. Gribble, Br. J. Pharmacol., 2012, 165, 414-423.

25 A. B. Petersen and M. Christensen, Diabetes, Metab. Syndr. Obes.: Targets Ther., 2013, 6, 217-231.

26 (a) M. Anzini, C. Braile, S. Valenti, A. Cappelli, S. Vomero, L. Marinelli, V. Limongelli, E. Novellino, L. Betti, G. Giannaccini, A. Lucacchini, C. Ghelardini, M. Norcini, F. Makovec, G. Giorgi and R. Ian Fryer, J. Med. Chem., 2008, 51, 4730-4743; (b) D. Heckmann, B. Laufer, L. Marinelli, V. Limongelli, E. Novellino, G. Zahn, R. Stragies and H. Kessler, Angew. Chem., Int. Ed., 2009, 48, 4436-4440; (c) M. Anzini, S. Valenti, C. Braile, A. Cappelli, S. Vomero, S. Alcaro, F. Ortuso, L. Marinelli, V. Limongelli, E. Novellino, L. Betti, G. Giannaccini, A. Lucacchini, S. Daniele, C. Martini, C. Ghelardini, L. Di Cesare Mannelli, G. Giorgi, M. P. Mascia and G. Biggio, J. Med. Chem., 2011, 54, 5694-5711.

27 Glide, version 7.1, Schrödinger, LLC, New York, NY, 2016. 